\section{Reflexes of Organizational Values on the Reward System in a Family Business}

\author{
Dalci Almeida ${ }^{1}$ \\ dalci.almeida@unisul.br | (DD 0000-0001-8967-0702 \\ Ilse Beuren ${ }^{1}$ \\ ilse.beuren@gmail.com | (D) 0000-0003-4007-6408 \\ Januario Monteiro ${ }^{1}$ \\ januariomonteiromonteiro@gmail.com | (D) 0000-0002-7000-4256
}

\begin{abstract}
This study analyzes the reflexes of organizational values in the reward system mediated by informal controls in a family business. A single entity survey was conducted at a family business that has 125 employees, and the sample consists of the 85 respondents to the questionnaire. In the analyses, the structural equation modeling technique was applied. The results show a positive relationship between the organizational values and the reward system, which indicates that the values of conformity, tradition, prestige, and concern for the community are related to monetary and non-monetary incentives in the investigated family business. Partial mediation of informal controls in this relationship was confirmed, which indicates that organizational values affect the rewards system through cultural and personal controls. The study contributes to the literature by revealing that organizational values aligned with informal controls are reflected in the reward system of family businesses, which implies directing managers' greater attention to these variables in organizational practice.
\end{abstract}

\section{KEYWORDS}

Organizational values, Informal controls, Rewards system, Family business
${ }^{1}$ Universidade Federal de Santa Catarina, Florianopolis, UFSC, SC, Brasil

Received: 03/08/2020

Revised: 06/25/2020.

Accepted: 07/29/2020.

Published Online: 02/22/2021.

DOI: http://dx.doi.org/10.15728/bbr.2021.18.2.2 


\section{INTRODUCTION}

Family businesses are considered the basis of the different forms of business observed in humanity so far (Britto Júnior \& Melo, 2014). Their peculiar characteristics differentiate them from non-family businesses, which can lead them to evaluate, acquire, group and leverage their resources differently from non-family businesses (Sirmon \& Hitt, 2003; Michiels, 2017). In general, research on family businesses tends to dissociate them from their cultural characteristics, despite the relevance of knowing these elements more deeply (Britto Júnior \& Melo, 2014).

Organizational values are principles and beliefs that guide the goals defined by the organization (Gosendo \& Torres, 2010). In this regard, family businesses require a differentiated management process, which takes into account behavioral issues and, mainly, their family values (Britto Júnior $\&$ Melo, 2014). In a family business, owners need to consolidate the interests of their trusted followers and deal with complex relationships, combining mutual interests and benefits and the challenges to break parental relationships and treat all employees equally (Wang, 2007; Lin, 2013).

The Theory of Human Values helps to better understand organizational values (Schwartz, 1992), as organization and individuals share objectives and goals that meet the needs of human beings. Organizational values can be based on human values, since they are based on personal motivations (Oliveira \& Tamayo, 2004). Schwartz (1992) proposes a typology of motivational values: tradition, stimulation, benevolence, hedonism, security, fulfillment, universalism, power, self-determination, and conformity. These motivational types of values may be involved in the management of family businesses which, according to Schwartz (2006), vary in importance and serve as principles of a social entity.

The organizational values were studied in various contexts, such as performance evaluation (Melo \& Domenico, 2012), human resources certification (Garza \& Morgeson, 2012), interaction of family values in management (Britto Júnior \& Mello, 2014), values communicated through informal controls (Kachelmeier, Thornock \& Williamson, 2015) and high performance work system (Özçelik, Aybas \& Uyargil, 2016). In family businesses, the evaluation of employee's performance can have a strong interaction with family values, given its role in reinforcing the organizational values and objectives. Reward systems also play an important role (Holbeche, 2009), such as reinforcing "what the organization wants to encourage in its professionals, to encourage certain behaviors and actions" (Marx, Soares \& Barros, 2016, p. 269).

Rewards are defined as any type of monetary, non-monetary, or psychological payment that an organization offers to its employees in exchange for work (Bratton \& Gold, 2012). Schiehll and Morissette (2000, p. 13) emphasize that reward systems consist of "written and/or unwritten promises of compensation incentives". Research on rewards systems in family businesses is still scarce, but they have been conducted in contexts such as: differences between family and nonfamily businesses based on incentive rewards systems (Lin, 2013), formalization of compensation practices in micro and small family businesses (Michiels, 2017).

Informal controls are also important to reinforce organizational values and objectives. They represent the unwritten norms that derive from the organizational culture (Langfield-Smith, 1997), and can be classified as personal and cultural (Goebel \& Weißenberger, 2016). They refer to the adequate training and development of employees or a consistent corporate culture in the behavior of the individuals (Goebel \& Weißenberger, 2016). There are other informal controls, such as the mission statement, which conveys the company's core values to employees, 
and the sharing of informal codes of conduct, which contribute to direct employee behavior in the company (Collier, 2005; Sandelin, 2008).

However, these informal controls have been little investigated and constitute a research gap (Goebel \& Weißenberger, 2016). In a broader context of managerial control, Malmi and Brown (2008) point out that there is a lack of research that examines the control package that organizations use to motivate employees, which instigates to explore the system of monetary and non-monetary rewards. The herein family business study was instigated by a gap observed in the literature that the knowledge about the relationship between organizational values and the reward system is limited. This scenario suggests research demands that identify the predictors of the rewards system (Honrado, Cunha \& Cesário, 2001).

In this perspective, the objective of this study is to analyze the reflexes of the organizational values on the reward system, mediated by informal controls in a family business. In the study, organizational values were analyzed based on the typology developed by Schwartz (1992), adapted by Oliveira and Tamayo (2004) for the organizational context. Among the ten motivational types of values of this typology, those that are considered most relevant to the context of the family business were selected: tradition, conformity, concern for the collective, and prestige. Structural equation modeling was applied to the data collected by the single-entity survey in a family business. The findings point to a positive relationship between organizational values and the rewards system, and partial mediation of informal controls in this relationship was confirmed, indicating that the organizational values affect the rewards system through cultural and personal controls.

This study contributes to the literature by exploring in depth, through a single case of a family business, the effects of the organizational values on the rewards system, in addition to analyzing the mediating effect of the informal controls (cultural and personal) in this relationship. Rewards systems are analyzed in both monetary and non-monetary terms, although family businesses tend to use more informal rewards (Michiels, 2017). The study poses to advance the literature by considering organizational values and the rewards system as multidimensional reflective constructions. It is conjectured that organizational values and informal controls are antecedents of the rewards system, an allusion made by Honrado, Cunha and Cesário (2001). This research, focused on informal controls, also contributes to the field of management accounting that requires attention in family businesses (Songini, Gnan \& Malmi, 2013), in this research, it is focused on informal controls.

The study also presents practical contributions by bringing forward discussions that generate learning for managers of family businesses, in particular, by revealing the organizational values present in a family organization and its effects on the reward system (monetary and non-monetary incentives), in order to identify and better select the informal controls that should be used to reinforce the organizational values and functions of the rewards system. The relevance of the study is to consider that the ways of making decisions and managing the activities of family businesses are different from non-family ones, due to the interaction of family life in business and socio-emotional attachment, impacting on controls, which are more flexible and less bureaucratic (Kalm \& Gomez-Mejia, 2016; Moreira \& Frezatti, 2019). 


\section{THEORETICAL BASIS AND HYPOTHESES}

\subsection{Organizational VALUES AND THE REWARDS SYSTEM}

Organizational values are "principles or beliefs, organized hierarchically, relating to types of structure or desirable behavioral models that guide the life of the company and are at the service of individual, collective or mixed interests" (Tamayo \& Gondim, 1996, p. 63). According to Britto Júnior and Melo (2014, p. 185) "they are principles and beliefs that, shared, guide the organization's functioning and life". Rokeach (1973) adds that they are related to the beliefs about the institutional goals shared by the individuals of the organization and help in the interpretation of the environment. They provide a system of meanings common to all (Rokeach, 1973) and direct "strategic choices and the effective functioning of organizations" (Ferreira, Fernandes $\&$ Silva, 2009, p. 86). That is why they are the essence of the organizational culture (Garza \& Morgeson, 2012).

In the work environment, employees perceive that organizational values are decisive for achieving efficiency in the organization, given that they are considered in employee evaluations. Values are used by management to shape behavior and drive the desirable organizational goals (Garza \& Morgeson, 2012). Thus, organizational values are related to how the organization faces problems arising from internal operations or the external environment (Britto Júnior \& Melo, 2014). Organizational values, as a reflection of organizational culture, are claimed to influence strategic issues, such as strategic change, decision making, and employee engagement, in addition to the interaction of the organization with external stakeholders (Özçelik, Aybas \& Uyargil, 2016).

The definition of organizational values must consider cognitive, motivational, hierarchical and functional elements (Tamayo \& Gondim, 1996). The cognitive element is basic, as the values represent beliefs existing in the organization, valued and emphasized, translating into behaviors accepted by it. The motivational element represents someone's interests and desires, the fundamental goals of the organization. The functional element is linked to the role of values, which consists in guiding the life of the organization. The hierarchical element emphasizes that the organizational values suggest preferences, and give different weights according to the value, as the organizations attach different importance to the values (Tamayo \& Gondim, 1996). These elements allow the organization to guide its employees' choices and attitudes (Toh, Morgeson \& Campion, 2008).

According to Özçelik, Aybas and Uyargil (2016), organizational values permeate the ways in which organizations use them to operationalize their organizational culture. Organizational values lay the foundations of organizational culture which, in turn, drive performance and are, therefore, highly significant for companies. Organizational values are dynamic in nature and can take different forms, including configuring themselves as shared values, if employees are asked what their values are (Özçelik, Aybas \& Uyargil, 2016).

Schwartz (2006, p. 57) considers values as "desirable transsituational goals, varying in importance, that serve as guiding principles in the life of a person or other social entity". The values were grouped by Schwartz (1992) into motivational types that constituted a typology of ten elements: achievement, self-direction, benevolence, stimulation, security, power, conformity, hedonism, tradition, and universalism. Oliveira and Tamayo (2004) built and validated a construct that measures the perception of organizational values in line with the motivational types developed by Schwartz (1992). They found evidence that organizational values are similar to personal values in relation to motivation. 
Thus, the factors proposed by Oliveira and Tamayo (2004) correspond to the motivations developed by Schwartz (1992). Among the factors, autonomy corresponds to self-direction and stimulation. The concern for the collective embodies universalism and benevolence. Prestige and dominance are part of the power factor. Chart 1 presents a summary of such correspondences.

Chart 1

Organizational values

\begin{tabular}{|c|c|c|c|}
\hline Type of motivation & Correspondence & Goals & Interests served \\
\hline Autonomy & $\begin{array}{l}\text { Self-direction } \\
\text { Stimulation }\end{array}$ & $\begin{array}{l}\text { Offer challenges and variety at work, } \\
\text { stimulating curiosity, creativity and } \\
\text { innovation. }\end{array}$ & Individual \\
\hline Welfare & Hedonism & $\begin{array}{l}\text { Promote satisfaction, welfare and quality of } \\
\text { life at work. }\end{array}$ & Individual \\
\hline Achievement & Achievement & $\begin{array}{l}\text { Value the competence and success of } \\
\text { workers. }\end{array}$ & Individual \\
\hline Dominance & Power & $\begin{array}{l}\text { Make profit, be competitive and dominate } \\
\text { the market. }\end{array}$ & Individual \\
\hline Prestige & Power & $\begin{array}{l}\text { Have prestige, become known and admired } \\
\text { by everyone, offer satisfactory products and } \\
\text { services to customers. }\end{array}$ & Individual \\
\hline Tradition & Tradition & $\begin{array}{l}\text { Maintain the tradition and respect the } \\
\text { organization's customs. }\end{array}$ & Collective \\
\hline Conformity & Conformity & $\begin{array}{l}\text { Promote righteousness, courtesy and good } \\
\text { manners at work and respect for the rules } \\
\text { of the organization. }\end{array}$ & Collective \\
\hline $\begin{array}{l}\text { Concern for the } \\
\text { collective }\end{array}$ & $\begin{array}{l}\text { Benevolence } \\
\text { Universalism }\end{array}$ & $\begin{array}{l}\text { Promote fairness and equality in the } \\
\text { organization, as well as tolerance, sincerity } \\
\text { and honesty. }\end{array}$ & $\begin{array}{l}\text { Collective and } \\
\text { mixed }\end{array}$ \\
\hline
\end{tabular}

Source: Schwartz (1992); Oliveira e Tamayo (2004).

Britto Júnior and Melo (2014) highlight that the organizational values determined by Oliveira and Tamayo (2004) correspond to the motivational types of Schwartz (1992). For Oliveira and Tamayo (2004, p. 129), "personal values are considered as indicators of the one's motivations, which both managers and workers take with them when they join the organization". In this perspective, for Britto Júnior and Melo (2014) organizational values correspond, to some extent, with personal values.

The function of these values, according to Tamayo (2005, p. 201), is "to create favorable conditions for the emergence and development of the well-being of the organization and the worker". In the same sense, Johnson and Jackson (2009) elucidate that values are decisive for the organization's success. According to Tamayo and Borges (2006, p. 422), organizational values "contribute to internal integration, motivate the achievement of goals and objectives and are imperative for organizational effectiveness". According to Tamayo (1998, p. 58), these "values determine the organizational productivity". 
The essence of the organizational values lies in their ability to influence the choices, priorities, actions and attitudes of the organization and employees (Williams, 2002; Toh, Morgeson \& Campion, 2008; Garza \& Morgeson, 2012). However, in family businesses they serve individual,

collective, and mixed interests. Individual interests respond to the demands of the members of the managing family. Collective and mixed groups serve the interests of the group, due to the greater acceptance and collective well-being between the family, the organization, and society (Britto Júnior \& Melo, 2014).

According to Honrado, Cunha and Cesário (2001, p. 281-282), organizations that "favor values such as cooperation encourage team spirit and a harmonious work environment, promote a reward system in which remuneration reflects the fair performance of the worker, making it possible to perceive a climate of fairness and equality". The rewards systems seek to motivate and increase the performance of individuals and groups, offering rewards to control the direction, duration, and intensity of the effort (Malmi \& Browm, 2008). This is because the organizational values determine the use of the rewards systems that aim to attract and motivate employees (Garza \& Morgeson, 2012).

The family business that has values such as tradition, compliance, concern for the collective and prestige tends to align its incentive systems, both monetary (e.g. commissions, bonuses, profit sharing and share-based payment), as well as non-monetary (ex: verbal recognition, valuations, awards/merits and recognition). Organizational values can be reflected in the reward system, in view of emerging family and corporate values. This is due to the emergence of new corporate cultures, which envision values such as customer satisfaction, services and quality production. Such values encourage special attention to concerns with people, such as self-realization, opportunities for full employment for men and women and intergenerational responsibility (Hanks \& Sussman, 1993).

In family businesses, culture has particular characteristics, the overlap of family values and business values, as well as the family's commitment to the business (Songini, Gnan \& Malmi, 2013). In the survey conducted by Michiels (2017), the results supported, based on the managerial capacity and the agency arguments, that a family businesses whose Chief Executive Officer (CEO) is a family member adopt significantly less formal remuneration practices than family companies led by a CEO who is not a member of the family. It is also presumed to happen in family businesses, due to their values, that, in addition to monetary rewards, there is the practice of non-monetary rewards, which instigates to study the set of incentives for employees.

In line with the purpose of analyzing the relationship of organizational values with the rewards system in a family business, the herein research considered the organizational values as a multidimensional construct, with the unidimensions of values of tradition, conformity, and concern for the collective, in addition to prestige that serves individual interests. It is a multidimensional construct, since these values together represent the organizational values and aim, in essence, to achieve the organization's objectives (Toh, Morgeson \& Campion, 2008; Michailova \& Minbaeva, 2012).

In this research, the rewards system was also considered as a multidimensional construct. Such a choice is justified by the fact that organizations use the rewards system to motivate employees (Garza \& Morgeson, 2012) and these forms of incentives are achieved with monetary and non-monetary rewards (Flamholtz, 1996) and are intertwined with the organizational culture (Flamholtz, 1996; Malmi \& Brown, 2008) embodied in the organizational values. Thus, the first hypothesis is: 
BBR

18

146

- H1: Organizational values (tradition, conformity, concern for the collective and prestige) are positively related to the rewards system (monetary and non-monetary).

\subsection{EFFECTS OF THE ORGANIZATIONAL VALUES ON THE REWARDS SYSTEM MEDIATED} BY INFORMAL CONTROLS

The traditional concept of managerial control has been refined, from a predominantly accounting perspective, to a more comprehensive or holistic perspective, comprising formal and informal management controls (Goebel \& Weißenberger, 2016). Management control systems have evolved over the years, while before they provided more formal and financially quantifiable information, currently they have a broader scope of information to assist in management decision making (Chenhall, 2003).

Langfield-Smith (1997) explain that formal controls concern rules, operating procedures, standards, and budget systems, which are the most objective components of the management control system, while informal controls are not consciously designed and include unwritten policies, but inherent to the organizational culture. Informal controls are important components of management control systems, affect employee perceptions and actions, for example, the selection and training approaches or the design of an integrated corporate culture that is based on shared values and beliefs (Flamholtz, 1996; Sandelin, 2008; Goebel \& Weißenberger, 2016).

For Goebel and Weißenberger (2016), management control systems consist of formal (results and/or action) and informal (personal and/or cultural) controls. In a survey conducted with 295 top management accountants, they examined how these control mechanisms are related to the effectiveness of the management control system and organizational commitment, and how these two results affect the organizational performance. The results revealed that more informal control mechanisms are strongly associated with beneficial results and support the growing relevance of more informal control mechanisms, as compared to formal control mechanisms.

An important distinction between the two forms of control is that formal controls are mainly associated with the allocation of extrinsic rewards (e.g., salary increases or higher levels of compensation of performance incentive), while informal controls are related to the provision of intrinsic rewards (e.g.: increased levels of autonomy or opportunities for personal development), which can have a more sustainable effect on behaviors, promoting intrinsic motivation (Epstein, 2008; Manzoni, 2008; Rost \& Osterloh, 2009; Goebel \& Weißenberger, 2016) .

If the values become prominent for the organizational culture, human resource practices must be incorporated into the organization's value system, which is the driving force behind positive organizational performance (Özçelik, Aybas \& Uyargil, 2016). Although rewards are often linked to cyber controls (budget, financial measures, non-financial and hybrid measures), the organizations also offer rewards and compensations for other reasons. This includes retaining employees and encouraging cultural control through group rewards. Therefore, research needs to consider alternative reward and compensation schemes, their intended purposes and their connections with various controls (Malmi \& Browm, 2008). In view of the theoretical-empirical evidence, the second hypothesis is:

- H2: Informal controls (personal and cultural) mediate the relationship between organizational values and the rewards system. 
In line with the hypotheses proposed, Figure 1 presents the theoretical model of the research.

Through Figure 1, the study predicts that the organizational values (tradition, conformity, concern for the collective and prestige) are positively related to the rewards system (monetary and non-monetary incentives), and that this relationship can be mediated by informal controls (personal and cultural). Thus, it supports that the organizational values are related to the rewards system $\left(\mathrm{H}_{1}\right)$ and this relationship is mediated by informal controls $\left(\mathrm{H}_{2}\right)$.

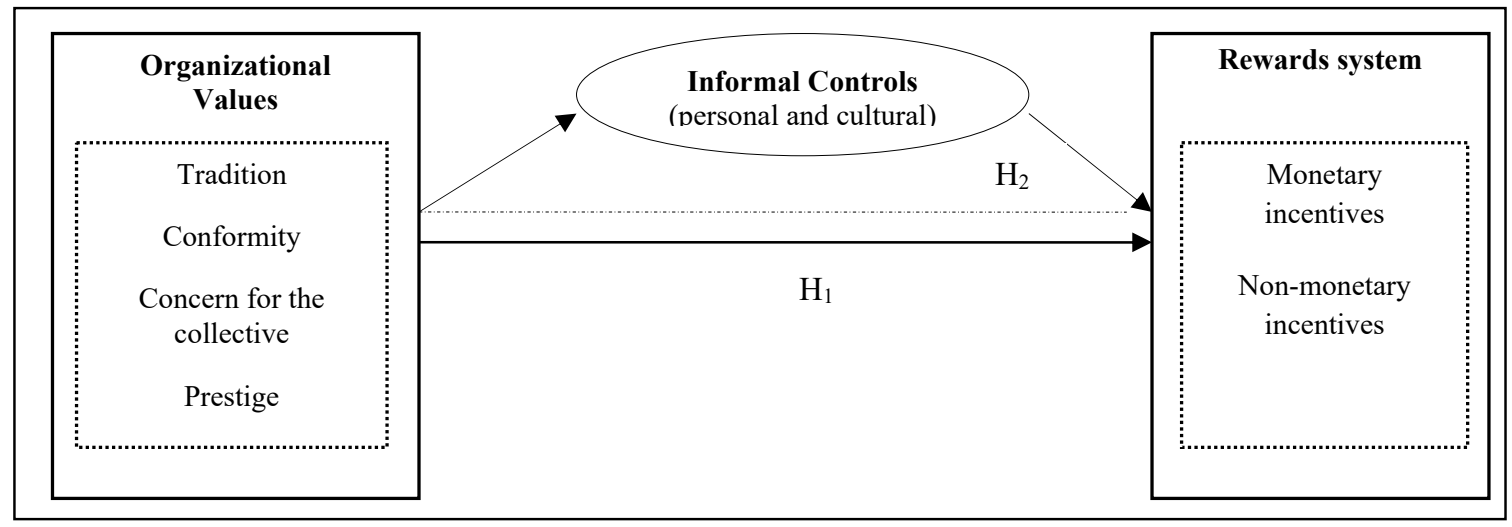

Figure 1. Conceptual model proposed.

Source: Prepared by the authors.

\section{METHODOLOGICAL PROCEDURES}

A single entity survey was conducted through an electronic questionnaire sent to employees of a family business. This method was chosen because of the importance of studying the research problem in depth, considering a single organizational context. According to Mucci, Frezatti and Dieng (2016), this type of methodology can reflect the beliefs of the organization as a whole, as well as of several areas.

A research protocol was developed to present the purposes of the study to the managers at the top of the hierarchy, to define the collection process, the procedures of data analysis, and the contributions of the study. They were informed about the confidentiality of the data and its exclusive use for academic purposes. The survey instrument was sent by the company's human resources department to 125 employees who have an email account, from March to November, 2019.

\subsection{CASE SELECTION AND DATA COLlECTION}

The company selected is a large corporation which has been operating in the plastic and aluminum extrusion business for 40 years. It was selected for being a family business and has well-structured and recognized management processes. The origin and history of the company are linked to a family that, until now, was part of the company's management. Family business is based on family traditions and values and is defined by Bernhoeft (1989, p. 35) as "one that has its origin and its history linked to a family, or also, one that keeps family members in the administration of the business".

First, the quality supervisor was contacted to check if the company had the characteristics necessary for the study. Then, the daughter of one of the owners, who works in human resources, was contacted and received detailed information about the purpose of the research, the data 
collection instrument, the way the research was carried out, and the practical implications of the study for the company. It was exposed that the research population comprised employees at the level of management, coordination, analysts, and subordinates from different areas of the organization, which totalized 125 employees, and the sample consisted of 85 respondents, representing $68 \%$ of the population.

The minimum number of responses and the non-response bias were analyzed (Wåhlberg \& Poom, 2015). Considering two arrows in the dependent variable, 0.15 effect, $5 \%$ significance and the power of $1-\beta=0.8$, through $G^{*}$ power (Faul, Erdfelder, Buchner $\&$ Lang, 2009) it was found that 68 respondents is the minimum for the model. This criterion was met as the sample consists of 85 valid responses. Regarding the Non-Reponse Bias, there was no significant difference between the first and the last 17 respondents, which indicates that there is no non-response bias.

\subsection{Measurement of the Variables and analysis procedures}

All constructs in the research were measured using multiple items, with statements taken or adapted from previous studies. Each measurement was anchored on a five-point Likert scale. The research instrument (Appendix A) was tested and revised by a researcher in the field and two controllers, who suggested small changes in the writing of some statements, aiming at a better understanding by the respondents.

\subsubsection{Organizational values}

The construct proposed by Oliveira and Tamayo (2004) was chosen to measure the organizational values. In the original research, each item was hypothetically described according to the profile of an organization. Each profile contained goals, pretensions or desires that implicitly pointed to the important role of the organizational values. The possible responses were: "Very similar to my organization"; "Similar"; "More or less similar"; "A little similar"; "It is not similar to my organization"; "It is not similar to my organization at all".

This original scale was changed in this research to four organizational values: tradition, with five statements; compliance, with seven; concern for the collective, with seven; and prestige, with four statements. It is noteworthy that, despite this adaptation, the statements were similar to the ones in the original study. The respondents were asked to indicate their degree of agreement with these statements, on a scale from 1 (strongly disagree) to 5 (strongly agree). The exploratory factor analysis confirmed the consistency of the construct (Fávero, 2017), with KMO of 0.846, significant by the Bartlett test $\left(\mathrm{X}^{2}=1337.34\right.$; Sig $\left.=0.000\right)$, and commonality over 0.50 .

\subsubsection{Informal controls}

The research instrument of Goebel and Weißenberger (2016) was used in the construct of informal controls, exposing cultural controls with six statements and personal controls with five. Respondents were asked to indicate their degree of agreement with these statements, on a scale from 1 (disagree) to 5 (strongly agree).

The exploratory factor analysis confirmed the consistency of the construct, with KMO of 0.892 , significant by the Bartlett test $\left(\mathrm{X}^{2}=702.14\right.$; Sig $\left.=0.000\right)$, and commonality greater than 0.50 , with the exception of the indicators "training activities and development for employees are considered very important", with 0.497 , and "employees receive numerous opportunities to expand their skills", with 0.489 . Although they are below the recommended, it was decided not to remove them as this instrument has already been tested (Goebel \& Weißenberger, 2016), and captures elements relevant to the research. 
Lin's research instrument (2013) was adapted for the rewards system construct, some assertions that do not apply to the family business were excluded and others were included. The rewards system consists of monetary and non-monetary incentives, with four items each. Respondents were asked to indicate their degree of agreement with these statements, on a scale from 1 (strongly disagree) to 5 (strongly agree). The exploratory factor analysis confirmed the consistency of the construct, with KMO of 0.892 , significant by the Bartlett test $\left(\mathrm{X}^{2}=613.03\right.$; $\left.\mathrm{Sig}=0.000\right)$, and commonality greater than 0.50 .

The data analysis process was based on the use of structural equation modeling (SEM) according to the estimation of Partial Least Squares (Partial Least Squares - PLS), as provided by Hair Jr., Hult, Ringle and Sarstedt (2016). This technique involves three main stages of analysis: PLS algorithm, bootstrapping, and blindfolding. According to Chin (1998), it is consistent for research with a small sample.

\section{DATA DESCRIPTION AND ANALYSIS}

\subsection{MeAsurement MOdeL}

Structural equation modeling starts with the measurement model. Initially, the reliability of the research instrument is verified by Cronbach's alpha and the compound reliability. Hair Jr., Gabriel and Patel (2014) point out that Cronbach's alpha is sensitive to scale items, whereas composite reliability is not. It follows the convergent validity, measured by the Average Variance Extracted (AVE), and the discriminant validity, evaluated by the criteria of the matrix Fornell and Larcker and the crossloading (Hair Jr. et al., 2016). Table 1 presents the measurement model.

Table 1

Measurement model

\begin{tabular}{|c|c|c|c|c|c|c|c|}
\hline \multirow{2}{*}{ Constructs } & \multirow{2}{*}{$\begin{array}{c}\text { Cronbach's } \\
\text { Alpha }\end{array}$} & \multirow{2}{*}{$\begin{array}{l}\text { Composite } \\
\text { Reliability }\end{array}$} & \multirow{2}{*}{$\begin{array}{l}\text { Average Variance } \\
\text { Extracted (AVE) }\end{array}$} & \multirow{2}{*}{$\mathrm{R}^{2}$} & \multicolumn{3}{|c|}{ Discriminant Validity } \\
\hline & & & & & $\mathrm{IC}$ & $\mathrm{RS}$ & $\mathrm{OV}$ \\
\hline $\begin{array}{l}\text { Informal Controls } \\
\text { (IC) }\end{array}$ & 0.931 & 0.942 & 0.600 & 0.571 & 0.775 & & \\
\hline $\begin{array}{l}\text { Rewards System } \\
\text { (RS) }\end{array}$ & 0.946 & 0.957 & 0.918 & 0.371 & 0.579 & 0.959 & \\
\hline $\begin{array}{l}\text { Organizational Values } \\
(\mathrm{OV})\end{array}$ & 0.900 & 0.985 & 0.633 & & 0.756 & 0.562 & 0.795 \\
\hline
\end{tabular}

Note: Cronbach's Alpha >0.70; Composite Reliability $>0.70$; Average Variance Extracted (AVE) $>0.50$.

Source: Prepared by the authors.

The three constructs have Cronbach's alpha greater than 0.70 (Table 1), which indicates that the proposed relationships are congruent with the literature, and that the research instrument is reliable. It should be noted that the variables rewards system and organizational values are of second order, and their multidimensionalities have been attested. The composite reliability also showed results greater than 0.70 , indicating that the model is adequate.

In the convergent and discriminant validities it is also noted that the constructs are valid, since the AVE was greater than 0.50 and the discriminant validity meets the Fornell and Larcker and crossloading criteria (Hair Jr. et al., 2016). The discriminant validity by the Fornell and Larcker criteria allows examining the degree of distinction between the constructs (Hair Jr. et al., 2016). 
The results show that the constructs are distinct. In general, the results of the measurement model indicate that the constructs have reliability and validity, being possible to verify the estimation relationships of the paths.

\subsection{Structural MOdel}

The second step in modeling structural equations is to assess the structural relationships. It was performed using the Bootstrapping technique, which follows the parameters of 5,000 subsamples and interactions that establish a path diagram. This, in turn, makes it possible to reject or not the hypotheses (Hair Jr. et al., 2016). It is noteworthy that the confidence interval had corrected and accelerated to 5\%, two-tailed bias. Table 2 shows the relation between the constructs.

Table 2

Structural model

\begin{tabular}{lcccc}
\hline \multicolumn{1}{c}{ Relation between constructs } & $\beta$ & T-value & P-value & Hypotheses \\
\hline Organizational Values $\rightarrow$ Rewards System & 0.290 & 2.180 & $0.030^{* *}$ & \\
Informal Controls $\rightarrow$ Rewards System & 0.360 & 2.822 & $0.005^{* * *}$ & $\mathrm{H}_{1}$ Confirmed \\
Organizational Values $\rightarrow$ Informal Controls & 0.756 & 14.873 & $0.000^{* * *}$ & \\
\hline $\begin{array}{l}\text { Organizational Values } \rightarrow \text { Informal Controls } \rightarrow \\
\text { Rewards System }\end{array}$ & 0.272 & 2.591 & $0.010^{* * *}$ & $\begin{array}{c}\mathrm{H}_{2} \text { Partially } \\
\text { confirmed }\end{array}$ \\
\hline
\end{tabular}

Note: $\mathrm{N}=85$. Significance at the level of ${ }^{*} \mathrm{p}<0.10 ;{ }^{* *} \mathrm{p}<0.05 ;{ }^{* * *} \mathrm{p}<=0.01$.

$R^{2}=$ CI (0.571); SR (0.371). Q ${ }^{2}=$ CI (0.314); SR (0.246).

Source: Prepared by the authors.

The first hypothesis $\left(\mathrm{H}_{1}\right)$ predicted a positive relationship between organizational values and the rewards system. The results showed that the organizational values are positively and significantly related to the rewards system $(0.290, \mathrm{p}<0.05)$, which supports the non-rejection of $\mathrm{H}_{1}$, at the significance level of $5 \%$. It is inferred that the organizational values (tradition, conformity, concern for the collective, and prestige) enabled the employees of the company investigated to perceive in the company's reward system the existence of monetary incentives (e.g. commissions, bonuses, profit sharing, payment based on shares) and non-monetary incentives (e.g. verbal recognition, valuations, awards/merits, public recognition) (Lin, 2013).

The second hypothesis postulated that informal controls mediate the relationship between the organizational values and the rewards system. The results support the non-rejection of $\mathrm{H}_{2}$, since the indirect effect was positive and significant at the level of $1 \%(0.272, \mathrm{p}=0.01)$. Thus, the mediation is partially confirmed. Bido and Silva (2019) point out that when the direct relationship is significant and the indirect relationship is significant, partial mediation occurs.

The discussion underlying this hypothesis is based on the arguments that, in family businesses, informal controls (cultural and personal) may be more evident. This is due to the interaction between the family system, oriented towards emotion and focused on non-economic objectives; and the business system, oriented towards results and focusing on economic objectives (Distelberg \& Sorenson, 2009; Stockmans, Lybaert \& Voordeckers, 2010). Songini, Gnan and Malmi (2013) observed in their research the distinctive characteristics of family businesses that affect the managerial role and the impact of accounting on family businesses: (i) family involvement in ownership, management and governance; (ii) socio-emotional wealth; and (iii) succession. The involvement of family members in the management affects the adoption of monitoring and controlling mechanisms. 
A better dissemination of cultural and personal controls in family businesses can lead to a better understanding of the rewards system, which plays an important role in motivating employees and in the performance of their tasks (Goebel \& Weißenberger, 2016). Informal controls are considered important components of the management control system, as they affect employees' perceptions and actions (Flamholtz 1996; Sandelin, 2008; Goebel \& Weißenberger, 2016).

The accuracy of the model is verified by the Stone-Geisser indicator $\left(\mathrm{Q}^{2}\right)$, since $\mathrm{Q}^{2}$ was 0.314 for informal controls and 0.246 for rewards system. The predictive validity attested by Pearson's coefficient of determination $\left(\mathrm{R}^{2}\right)$ indicates that the independent variables poses an explanation of great effect to the dependent variable, with $\mathrm{R}^{2}$ of 0.371 in the rewards system and 0.571 in the informal controls.

\subsection{Discussion OF RESULTS}

To illustrate the significant relations that support the non-rejection of the hypotheses, Figure 2 is presented.

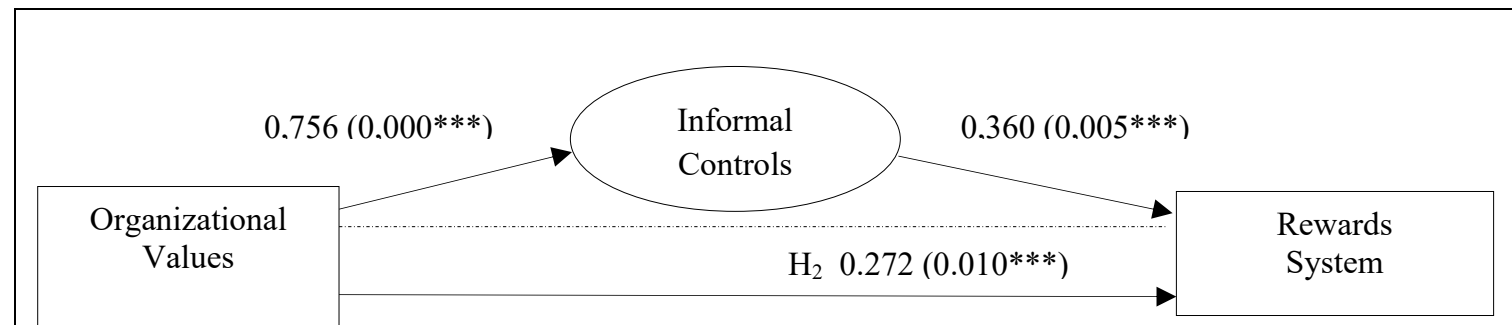

$\mathrm{H}_{1} 0.290\left(0,030^{* *}\right)$

Figure 2. Result of the path coefficients and p-value.

Note: $\mathrm{N}=85$. Significance at the level of ${ }^{*} \mathrm{p}<0.10 ;{ }^{* *} \mathrm{p}<0.05 ;{ }^{* * *} \mathrm{p}<=0.01$

Source: Prepared by the authors.

The first hypothesis expected a direct and positive relationship between organizational values and rewards system. By proposing that tradition, conformity, concern for the collective and prestige (organizational values) are related to monetary and non-monetary incentives (reward system), it was possible to confirm this relationship at the level of $5 \%$ of significance $(0.290$, $\mathrm{p}<0.05)$. It was inferred that, in the investigated company, the employees perceive the existence of values that favor the establishment of models of desirable behavior, in order to meet individual and collective interests (Tamayo \& Gondim, 1996).

The results are in line with those of Bedani's research (2012), due to organizational values, providing a range of principles that guide actions and multiple behaviors in the work environment. These values allow the creation of favorable conditions for work (Tamayo, 2005). This denotes the company's concern for well-being in the workplace, which is supported by a rewards system that offers monetary and non-monetary incentives to employees. This is congruent with the propositions of Tamayo (2005) and Bratton and Gold (2012). It also agrees with the findings of Demo, Fernandes and Fogaça (2017), that organizational values influence organizational behaviors and practices.

In the family business investigated, there is a concern to offer fair remuneration to its employees and motivate them based on verbal recognition and awards, among other actions (Honrado, Cunha \& Cesário, 2001), which is evidence of the presence of informal controls. The results show that 
BBR

18

152

organizational values have a positive and significant relationship with informal controls $(0.756$, $\mathrm{p}<0.01)$. It corroborates with Britto Júnior and Melo (2014), who point out that the organizational values are linked to the principles, beliefs, and values that guide the organization's functioning. In turn, informal controls are positively related to the rewards system $(0.360, \mathrm{p}<0.01)$. Goebel and Weißenberger (2016) point out that informal controls aim to promote greater motivation to individuals, based on monetary and non-monetary rewards.

In hypothesis $\mathrm{H}_{2}$, the effect of mediation of informal controls on the relationship between organizational values and the rewards system was tested. $\mathrm{H}_{2}$ is partially confirmed, since informal controls partially mediated the relationship $(0.272, \mathrm{p}=0.01)$. It is inferred that organizational values, such as tradition, conformity, concern for the collective, and prestige, together with personal and cultural controls, make it possible to build a reward system composed of monetary and non-monetary incentives. These arguments are in line with those of Honrado, Cunha and Cesário (2001), as they point out that organizational values favor cooperation, team spirit, fair remuneration, and well-being. In the investigated company, the selection, training and construction of a solid corporate culture is based on the company's values and beliefs. This is congruent with Goebel and Weißenberger (2016), who found a relationship between organizational values and rewards system in the perception of employees.

In general, employees perceive that the organizational values, such as tradition conformity, concern for the collective, and prestige, lead to a rewards system that favors the interests of the collective, and that the process of selection, training, and consolidation of the family culture (informal controls) allows them to feel part of the company and even of the family, with greater motivation at work (Epstein, 2008; Manzoni, 2008; Rost \& Osterloh, 2009; Goebel \& Weißenberger, 2016). These results have implications for the management of family businesses, since it makes evident the relevance of the alignment of the organizational values, when outlining the reward system, as well as the interference of informal controls in this relationship.

\section{FINAL CONSIDERATIONS}

This study analyzed the effects of organizational values in the rewards system mediated by informal controls in a family business, through a single entity survey. Empirical evidence revealed that values such as tradition, conformity, concern for the collective, and prestige (organizational values) are related to monetary and non-monetary rewards (rewards system). They also revealed that cultural controls (values and norms, communication of company values to employees) and personal controls (care in selecting employees, emphasis on hiring the most suitable candidates for the specific job position, importance attributed to the activities of training and development of employees) partially mediate the relationship between organizational values and the rewards system.

\subsection{THEORETICAL IMPLICATIONS}

This research contributes to the literature by analyzing the relationship between organizational values and the rewards system and the mediation of informal controls in this relationship. It also contributes by examining a multidimensional approach to the rewards system (monetary and non-monetary) in a family business, which has more informal rewards characteristics (Michiels, 2017). Previous research has focused on organizational values with a focus on performance evaluation (Melo \& Domenico (2012), human resources certification (Garza \& Morgeson, 2012), interaction of family organizational values in management (Britto Júnior \& Mello, 2014), 
high-performance work system (Özçelik, Aybas \& Uyargil, 2016) and organizational values as informal controls (Kachelmeier, Thornock \& Williamson, 2015).

The rewards systems, in turn, were investigated based on the differences between family and non-family businesses (Lin, 2013), and formalization of compensation practices in small family businesses (Michiels, 2017). Therefore, this study contributes to the literature on family business management, mainly by filling the perceived research gap regarding the influence of organizational values in the rewards system, and how this relationship can be influenced by the informal cultural and personal controls of family businesses.

\subsection{Practical implications}

The research results have practical implications as they reveal that organizational values (tradition, conformity, concern for the collective and prestige) (Oliveira \& Tamayo, 2004) have a direct relationship with the rewards system (monetary and non-monetary incentives) (Lin, 2013) in family business. This suggests that managers need to pay attention when selecting the most appropriate monetary rewards practices (e.g. commissions, bonuses, profit sharing) and nonmonetary rewards practices (e.g. verbal recognition, valuations, awards/merits and recognition) (Lin, 2013), in a family organizational environment, in which specific organizational values are present, such as respect for hierarchy, courtesy, the preservation of old customs, and the restriction on changes (Oliveira \& Tamayo, 2004). The results also warn of the need for managers to pay attention to the selection of informal controls (cultural and personal) that better define the rewards system in line with the organizational values. For Demo, Fernandes and Fogaça (2017), organizational principles can assist in the identification of organizational values, impact on organizational routines, and generate information that improves the decision-making process.

\subsection{LIMITATIONS AND RECOMMENDATIONS}

This study has limitations that can stimulate further research. The research was carried out in a single family organizational context, despite comprising employees from different organizational areas and allowing for depth, thus limiting the generalization of the results. The research is restricted to the subjects' perceptions about organizational values, informal controls, and the rewards system. Thus, the results may be associated with subjectivity in responses and social desire (Goebel \& Weißenberger, 2016). Responses to the questionnaire may also have suppressed aspects of privacy (Lin, 2013), which suggests the use of other research methods. Finally, other theoretical models could be adopted, although this paper used the constructs considered most appropriate to the proposed objective. Michiels (2017) highlights that, although the best practices are carefully selected based on the literature available, it is possible that the findings are sensitive to the selection of the investigated practices.

\section{REFERENCES}

Bedani, M. (2012). O impacto dos valores organizacionais na percepção de estímulos e barreiras à criatividade no ambiente de trabalho. Revista de Administração Mackenzie, 13(3), 150-176. doi: 10.1590/S1678-69712012000300008.

Bernhoeft, R. (1989). Empresa familiar: Sucessão profissionalizada ou sobrevivência comprometida. Nobel, São Paulo.

Bido, D.S., \& Silva, D. (2019). SmartPLS 3: Especificação, estimação, avaliação e relato. Administração: Ensino e Pesquisa, 20(2), 488-536. doi: 10.13058/raep.2019.v20n2.1545 
BBR

18

154

Bratton, J., \& Gold, J. (2012). Human resource management: Theory and practice (5 ed.). Palgrave Macmillan, Basingstoke.

Britto Júnior, A.F., \& Melo, M.C.O.L. (2014). A interação dos valores familiares na gestão de uma empresa familiar mineira: u m estudo de caso no grupo Zema. Revista de Gestão, 21(2), 183-199. doi: $10.5700 /$ rege 525 .

Collier, P.M. (2005). Entrepreneurial control and the construction of a relevant accounting. Management Accounting Research, 16(3), 321-339. doi: 10.1016/j.mar.2005.06.007.

Chenhall, R.H. (2003). Management control systems design within its organizational context: Findings from contingency-based research and directions for the future. Accounting, Organizations and Society, 28(2-3), 127-168. doi: 10.1016/s0361-3682(01)00027-7.

Chin, W.W. (1998). The partial least squares approach to structural equation modeling. Modern Methods for Business Research, 295(2), 295-336.

Demo, G., Fernandes, T., \& Fogaça, N. (2017). A Influência dos Valores Organizacionais na Percepção de Políticas e Práticas de Gestão de Pessoas. REAd. Revista Eletrônica de Administração, 23(1), 89117. doi: 10.1590/1413-2311.093.57040.

Distelberg, B., \& Sorenson, R.L. (2009). Updating systems concepts in family businesses. Family Business Review, 22(1), 65-81. doi: 10.1177/0894486508329115

Epstein M.J. (2008). Aligning, measuring, and rewarding performance in complex organizations. In: Epstein, M.J., \& Manzoni, J.F. (eds.). Performance measurement and management control: Measuring and rewarding performance (pp. 3-17). Emerald, Bingley.

Fávero, L.P. (2017). Análise de dados: Técnicas multivariadas exploratórias com SPSS e Stata. Elsevier, São Paulo.

Faul, F., Erdfelder, E., Buchner, A., \& Lang, A.G. (2009). Statistical power analyses using G* Power 3.1: Tests for correlation and regression analyses. Behavior Research Methods, 41(4), 1149-1160. doi: $10.3758 / \mathrm{brm} .41 .4 .1149$

Ferreira, M.C., Fernandes, H.A., Silva, A.P.C. (2009). Valores organizacionais: um balanço da produção nacional do período de 2000 a 2008 nas áreas de administração e psicologia. Revista de Administração Mackenzie, 10(3), 84-100. doi: 10.1590/S1678-69712009000300006.

Flamholtz, E. (1996). Effective organizational control: A framework, applications, and implications. European Management Journal, 14(6), 596-611. doi: 10.1016/s0263-2373(96)00056-4

Garza, A. S., \& Morgeson, F. P. (2012). Exploring the link between organizational values and human resource certification. Human Resource Management Review, 22(4), 271-278. doi: 10.1016/j. hrmr.2012.06.011

Goebel, S., \& Weißenberger, B.E. (2016). Effects of management control mechanisms: towards a more comprehensive analysis. Journal of Business Economics, 87(2), 185-219. doi:10.1007/s11573016-0816-6.

Gosendo, E.E.M., \& Torres, C.V. (2010). Influência dos valores organizacionais sobre estilos de gerenciamento em empresas de pequeno porte. Paideia, 20(45), 29-38. doi: 10.1590/S0103$863 X 201000010000$.

Hair Jr., J.F., Gabriel, M.L.D.D.S., \& Patel, V.K. (2014). Modelagem de equaçôes estruturais baseada em covariância (CB-SEM) com o AMOS: Orientações sobre a sua aplicação como uma ferramenta de pesquisa de marketing. Revista Brasileira de Marketing, 13(2), 44-55. doi: 10.5585/ remark.v13i2.2718 
Hair Jr., J.F., Hult, G.T.M., Ringle, C., \& Sarstedt, M. (2016). A primer on partial least squares structural equation modeling (PLS-SEM). Sage Publications, Thousand Oaks.

Hanks, R.S., \& Sussman, M.B. (1993). Rethinking family / organization linkage in job-related transfers. Marriage \& Family Review, 19(1-2), 99-111. doi: 10.1300/j002v19n01_06

Holbeche, L. (2009). Aligning human resources and business strategy (2 ed.). Butterworth-Heinemann, Oxford.

Honrado, G., Cunha, M.P., \& Cesário, F.J. (2001). Sistemas de recompensa: Uma análise empírica de antecedentes e consequências. Análise Psicológica, 19(2), 279-298.

Johnson, R. E., \& Jackson, E. M. (2009). Appeal of organizational values is in the eye of the beholder: The moderating role of employee identity. Journal of Occupational and Organizational Psychology, 82(4), 915-933. doi: 10.1348/096317908X373914

Kachelmeier, S.J., Thornock, T.A., \& Williamson, M.G. (2015). Communicated values as informal controls: Promoting quality while undermining productivity? Contemporary Accounting Research, 33(4), 1411-1434. doi: 10.1111/1911-3846.12147.

Kalm, M., \& Gomez-Mejia, L.R. (2016). Socioemotional wealth preservation in family firms. Revista de Administração, 51(4), 8-10. doi: 10.1016/j.rausp.2016.08.002

Langfield-Smith, K. (1997). Management control systems and strategy: A critical review. Accounting. Organizations and Society, 22(2), 207-232.

Lin, W.B. (2013). Research on knowledge sharing and interpersonal relationships: Empirical study of family firms and non-family firms. Quality and Quantity, 47(1), 151-166. doi: 10.1007/s11135011-9509-y.

Marx, R., Soares, J.P.R.F., \& Barros, L. (2016). Variáveis de contexto organizacional a serem consideradas no projeto de sistemas de recompensas orientados à inovação de produtos. Revista Brasileira de Gestão de Negócios, 18(60), 267-289. doi: 10.7819/rbgn.v18i60.2822.

Malmi, T., \& Brown, D.A. (2008). Management control systems as a package-Opportunities, challenges and research directions. Management Accounting Research, 19(4), 287-300. doi: 10.1016/j. mar.2008.09.003

Manzoni, J.F. (2008). On the folly of hoping for A, simply because you are trying to pay for A. In: Epstein, M.J., \& Manzoni, J.F. (eds.). Performance measurement and management control: Measuring and rewarding performance (pp.19-41). Emerald, Bingley.

Melo, W.F., \& Domenico, S.M.R. (2012). A influência dos valores organizacionais no desempenho de agências bancárias. Revista de Administração Contemporânea, 16(1), 137-156. doi:10.1590/ S1415-65552012000100009.

Michiels, A. (2017). Formal compensation practices in family SMEs. Journal of Small Business and Enterprise Development, 24(1), 88-104. doi: 10.1108/jsbed-12-2015-0173.

Moreira, L.V.M., \& Frezatti, F. (2019). O papel do sistema de controle gerencial na transiçáo entre estágios do ciclo de vida organizacional em uma empresa familiar. Revista Universo Contábil, 15(1), 65-84. doi: 10.4270/ruc.2019104

Mucci, D.M., Frezatti, F., \& Dieng, M. (2016). As múltiplas funções do orçamento empresarial. Revista de Administração Contemporânea, 20(3), 283-304. doi: 10.1590/1982-7849rac2016140121. 
BBR

18

156

Özçelik, G., Aybas, M., \& Uyargil, C. (2016). High performance work systems and organizational values: Resource-based view considerations. Procedia - Social and Behavioral Sciences, 235, 332341. doi: $10.1016 /$ j.sbspro.2016.11.040

Oliveira, A.F., \& Tamayo, A. (2004). Inventário de perfis de valores organizacionais. Revista de Administração da USP, 39(2), 129-140.

Rokeach, M. (1973). The nature of human values. Free Press, New York.

Rost, K., \& Osterloh, M. (2009). Management fashion pay-for-performance. Schmalenbach Bus Rev, 61(2), 119-149.

Sandelin, M. (2008). Operation of management control practices as a package - A case study on control system variety in a growth firm context. Management Accounting Research, 19(4), 324-343. doi: 10.1016/j.mar.2008.08.002.

Schiehll, E., \& Morissette, R. (2000). Motivation, measurement and rewards from a performance evaluation perspective. Revista de Administração Contemporânea, 4(3), 07-24. doi: 10.1590/s141565552000000300002 .

Songini, L., Gnan, L., \& Malmi, T. (2013). The role and impact of accounting in family business. Journal of Family Business Strategy, 4(2), 71-83. doi: 10.1016/j.jfbs.2013.04.002.

Stockmans, A., Lybaert, N., \& Voordeckers, W. (2010). Socioemotional wealth and earnings management in private family firms. Family Business Review, 23(3), 280-294. doi: 10.1177/0894486510374457.

Schwartz, S.H. (1992). Universals in the content and structure of values: Theoretical advances and empirical tests in 20 countries. In: Zanna, M. (Org.). Advances in experimental social psychology (v. 25, pp.1-65). Academic Press, Orlando.

Schwartz, S.H. (2006). Há aspectos universais na estrutura e no conteúdo dos valores humanos? In: Ros, M., \& Gouveia, V.V. (Orgs.). Psicologia social dos valores humanos: Desenvolvimentos teóricos, metodológicos e aplicados (pp.55-85). Senac, São Paulo.

Sirmon, D.G., \& Hitt, M.A. (2003). Managing resources: Linking unique resources, management, and wealth creation in family firms. Entrepreneurship theory and practice, 27(4), 339-358. doi: 10.1111/1540-8520.t01-1-00013.

Tamayo, A. (1998). Valores organizacionais: Sua relação com satisfação no trabalho, cidadania organizacional e comprometimento afetivo. Revista de Administração da USP, 33(3), 56-63.

Tamayo, A. (2005). Valores organizacionais e comprometimento afetivo. Revista de Administração Mackenzie, 6(3), 192-213.

Tamayo, A., \& Borges, L.O. (2006). Valores do trabalho e das organizaçóes. In: Ros, M., \& Gouveia, V.V. (orgs.). Psicologia social dos valores humanos: Desenvolvimentos teóricos, metodológicos e aplicados (pp. 397-431). Senac, São Paulo.

Tamayo, A., \& Gondim, M.G.C. (1996). Escala de valores organizacionais. Revista de Administração da USP, 31(2), 62-72.

Toh, S. M., Morgeson, F. P., \& Campion, M. A. (2008). Human resource configurations: investigating fit with the organizational context. Journal of Applied Psychology, 93(4), 864. doi: 10.1037/00219010.93.4.864

Wang, C.L. (2007). Guanxi vs. relationship marketing: Exploring underlying differences. Industrial Marketing Management, 36(1), 81-86. doi: 10.1016/j.indmarman.2005.08.002. 
Wåhlberg, A.E., \& Poom, L. (2015). An empirical test of nonresponse bias in internet surveys. Basic and Applied Social Psychology, 37(6), 336-347. doi: 10.1080/01973533.2015.1111212.

Williams, S. L. (2002). Strategic planning and organizational values: Links to alignment. Human Resource Development International, 5(2), 217-233. doi: 10.1080/13678860110057638

\section{AUTHOR'S CONTRIBUTION}

DA - Construction of the idea and development of the research in all stages.

IB - Construction of the idea, monitoring and analysis of research development at all stages.

JM - Generation of statistical data and data analysis.

\section{CONFLICTS OF INTEREST}

The authors declare there's no interest conflict. 


\section{Tradition}

Indicate your perception of the importance your company attributes to the organizational value tradition in your organization, on the scale of 1 (Strongly disagree) to 5 (Strongly agree).

1. Seeks to maintain respected practices.

2. Preserves ancient customs.

3. Avoids changes.

4. Employee's behavior must show respect for customs.

5. Tradition is a characteristic of the company.

\section{Conformity}

Indicate your perception of the importance your company attributes to the organizational value of compliance, on a scale of 1 (Strongly disagree) to 5 (Strongly agree).

1. Believes that rules are important.

2. It is important to have defined behavior models.

3. Respect for hierarchy is part of their traditions.

4. Considers it important that employees behave politely in the workplace.

5. Believes that courtesy is important.

6. Considers the rules of coexistence important.

7. Assumes that employees must accept the work they have to do.

\section{Concern for the collective}

Indicate your perception of the importance your company attributes to the organizational value concern for the collective, on a scale of 1 (Strongly disagree) to 5 (Strongly agree).

1. Considers that all people should be treated equally.

2. Considers it important that all people are treated fairly.

3. Believes that one must be honest in any situation.

4. Considers loyalty important.

5. Believes in the value of honesty.

6. Assumes it is important to be loyal to its employees and customers.

7. Encourages sincerity between people.

\section{Prestige}

Indicate your perception of the importance your company attributes to the organizational value prestige, on a scale of 1 (Strongly disagree) to 5 (Strongly agree).

1. Has prestige (is known and admired) in the society (external environment).

2. Has influence in the society.

3. Influences other organizations.

4. Has prestige (is known and admired) by its employees. 


\section{Monetary incentives}

Check the extent to which the following material incentives represent your company's reward system, on a scale of 1 (Strongly disagree) to 5 (Strongly agree).

1. Commissions.

2. Bonus.

3. Participation in the results.

4. Share-based payment.

\section{Non-monetary incentives}

Check the extent to which the following non-material incentives represent your company's reward system, on a scale of 1 (Strongly disagree) to 5 (Strongly agree).

1. Verbal recognition.

2. Valuations.

3. Awards / Merits.

4. Public recognition.

3 Informal Controls (Goebel \& Weißenberger, 2016)

\section{Cultural controls}

Assess the extent to which the cultural controls described below represent your company, on a scale of 1 (Strongly disagree) to 5 (Strongly agree).

1. Traditions, values and norms play an important role in the company.

2. Great emphasis is placed on sharing unwritten rules of conduct with employees in the company.

3. The mission statement conveys the company's core values to employees.

4. Top managers communicate the company's core values to employees.

5. Employees are aware of the company's core values.

6. Employees perceive the values encoded in the mission statement as motivators.

\section{Personal controls}

Assess the extent to which the following personal controls represent your company, on a scale of 1 (Strongly disagree) to 5 (Strongly agree).

1. Employees are carefully selected according to their compliance to the company's values and standards.

2. Much effort has been made to establish the most suitable recruitment process for the company.

3. Emphasis is placed on hiring the most suitable candidates for a specific job position.

4. Training and development for employees are considered very important.

6. Employees are given numerous opportunities to expand their skills. 